\title{
Teachers' practices mediate the association between teachers' ideas and children's perceived participation in early childhood education
}

\author{
Nadine Correia $^{\mathrm{a}, *}$, Helena Carvalho ${ }^{\mathrm{b}}$, Margarida Fialho ${ }^{\mathrm{a}}$, Cecília Aguiar ${ }^{\mathrm{a}}$ \\ ${ }^{a}$ Instituto Universitário de Lisboa (ISCTE-IUL), CIS-IUL, Avenida das Forças Armadas, Edf. ISCTE-IUL, 1649-026 Lisbon, Portugal \\ ${ }^{\mathrm{b}}$ Instituto Universitário de Lisboa (ISCTE-IUL), CIES-IUL, Avenida das Forças Armadas, Edf. ISCTE-IUL, 1649-026 Lisbon, Portugal
}

\section{A R T I C L E I N F O}

\section{Keywords:}

Right to participate

Participation

Early childhood education

Teachers' ideas

Teachers' practices

Children's perceived participation

\begin{abstract}
A B S T R A C T
Participation is a fundamental right of all children. Its promotion is considered a key investment in children's well-being, crucial to support high-quality early childhood education (ECE). In this study we aimed to investigate if ECE teachers' ideas on children's participation were associated with children's perceived participation, analysing the mediating role of teachers' practices and dimensions of process quality.

Participants in this quantitative study were 336 children (163 boys) aged between 44 and 84 months, and 58 ECE teachers (all female) aged between 26 and 60 years old, from 24 randomly selected ECE centres in the Lisbon metropolitan area. Using multilevel modelling, given the hierarchical structure of data, we found that ECE teachers' ideas about participation do influence children's perceived participation, through teachers' perceived practices. Further, ECE teachers' perceived participation practices were associated with children's perceived participation, through observed participation practices and observed process quality. This study suggests the interdependence of the subjective and objective properties of ECE classrooms, and how both should inform our understanding of the conditions needed to promote children's participation.
\end{abstract}

\section{Introduction}

Participation is a fundamental right of all children and its promotion is considered a key investment in children's wellbeing (European Commission, 2013). Participation refers to children's right to freely express themselves and to experience respect and consideration for their intentions and views in everyday life. The recognition of children's right to participate was driven by the Convention on the Rights of the Child, specifically in its Article 12 (CRC; United Nations General Assembly, 1989). The CRC does not set a minimum age, nor does it limit the contexts in which children can express their views. Instead, children's participation is recommended from an early age, in all issues affecting them (Council of Europe, 2017), and according to General Comment No. 7, it should be implemented in early childhood (United Nations Committee on the Rights of the Child, 2005).

Early childhood education (ECE) settings are fundamental microsystems in young children's lives (e.g., Melhuish, 2014) and ECE teachers play a crucial role in promoting children's participation (Lundy, 2007). Therefore, in this study, we aimed to extend previous research by examining how ECE teachers perceive and, through their practices, support children's participation rights. We considered children's perspectives, by investigating whether children's perceived participation was associated with teachers' ideas and practices. So far, to the best of our knowledge, no study investigated ECE teachers' ideas and children's perceived participation simultaneously, nor tested associations between them. In addition, we added to the limited research on ECE quality and children's participation rights (e.g., Sheridan \& Samuelsson, 2001), by investigating whether ECE teachers' ideas on children's participation were associated with children's perceived participation, while analysing the mediating role of teachers' practices and dimensions of process quality.

\subsection{Children's right to participate and ECE quality}

Children's right to participate is fundamental to the creation of a positive social climate in educational settings, promoting child-centred learning (United Nations Committee on the Rights of the Child, 2009). Therefore, the implementation of children's right to participate has been described as a key indicator of high-quality ECE (e.g., Moser, Leseman, Melhuish, Broekhuizen, \& Slot, 2017; Sheridan \& Samuelsson, 2001). ECE quality involves both structural (e.g., regulatable features such as number of trained staff) and process features (i.e., experiences

\footnotetext{
* Corresponding author.

E-mail addresses: nadine_correia@iscte-iul.pt (N. Correia), helena.carvalho@iscte-iul.pt (H. Carvalho), ana_margarida_fialho@iscte-iul.pt (M. Fialho), cecilia.rosario.aguiar@iscte-iul.pt (C. Aguiar).
} 
afforded children such as teacher-child interactions and curriculum), with the former setting the conditions for high-quality process quality, and the latter setting the conditions for child development (Moser et al., 2017). Therefore, in this study, we focus on the promotion of children's right to participate as a feature of high-quality process quality.

Participation challenges traditional conceptions of teacher-child interactions, and the status of children and ECE professionals, leading to the redefinition of their roles, expectations, and practices (Bae, 2012). ECE teachers are pivotal in creating opportunities for meaningful participation for all children, by considering their perspectives and promoting their initiative and decision making (Doverborg \& Pramling, 1993; Save the Children, 2005). Therefore, understanding teachers' ideas and practices is key for improving educational processes (OECD, 2009).

The consideration of both ideas and practices is consistent with the bioecological model, which posits that contexts of human development include both objective properties (e.g., observed ECE teacher practices) and subjective experiences (e.g., ECE teachers' ideas; children's perceived participation) of those properties (Bronfenbrenner \& Morris, 2006). Within this theory, the construct of proximal processes (i.e., forms of interaction between organisms and the environment and primary mechanisms for human development) is also relevant to understand participation. Indeed, proximal processes (e.g., teacher-child interactions) vary as a function of the characteristics of the developing person (i.e., dispositions), of the immediate or more remote contexts (including the ECE microsystem), and the time periods in which they take place (Bronfenbrenner, 2005).

Improving the quality of the environment has been shown to increase the developmental power of proximal processes (Bronfenbrenner \& Morris, 2006). Relatedly, microsystems characterized by enduring reciprocal relationships are those in which development is enhanced. Specifically, high-quality ECE settings offer opportunities for children's participation through reciprocal teacher-child interactions. On the contrary, ECE microsystems characterized by a restricted range of activities and impoverished experiences, for instance in terms of reciprocity, contribute to developmental risk (Garbarino \& Ganzel, 2000).

\subsection{Teachers' ideas about children's right to participate in ECE}

Ideas are mental representations that may include values, beliefs, conceptions, expectations, or perceptions (Sigel, 1985). Previous studies on ECE teachers' ideas about children's right to participate reflect different levels of participation, as proposed by Hart (1992), from children being part of a group and being listened to (e.g., Johansson \& Sandberg, 2010); to participation in planning and decision making (Sandberg \& Eriksson, 2010; Turnšek, 2008; Zorec, 2015); or initiating independent activity and choice with teachers' support (Broström et al., 2015). Self-determination and management of everyday life are considered by ECE professionals as strong indicators of high participation, promoting children's sense of coherence and comprehension of what surrounds them (Sandberg \& Eriksson, 2010).

Teachers' ideas seem to be associated with ECE quality. Sheridan (2007) reported that teachers from high-quality settings held themselves responsible for including children in decision making, while teachers from low-quality ECE settings highlighted external factors as obstacles hindering their interactions with children. Importantly, while associations between teachers' ideas (e.g., beliefs) and teachers' practices have been documented (e.g., Fives \& Buehl, 2012), available evidence is mixed. On the one hand, there is research showing congruence between teachers' beliefs and practices, suggesting that teachers' beliefs have implications for their decisions and practices (e.g., Hegde \& Cassidy, 2009). On the other hand, there is research showing inconsistency between teachers' beliefs and observed classroom practices (e.g., Wilcox-Herzog, 2002), suggesting that the association between ECE teachers' beliefs and practices might be also influenced by teacher and context characteristics (Wilcox-Herzog, Ward, Wong, \&
McLaren, 2015).

Nevertheless, there is some evidence suggesting that ECE teachers' beliefs about children's right to participate may be associated with the adoption of participation practices (Samuelsson, Sheridan, \& Williams, 2006). For instance, ECE teachers with child-centred beliefs are more sensitive to children's perspectives, promoting more opportunities for children's participation (Koran \& Avci, 2017). Likewise, when teachers understand and reflect upon the complexities of children's participation, they are more likely to match their purposes and practices, effectively promoting children's right to participate (Niemi, 2019; Sinclair, 2004).

\subsection{Teachers' practices towards the promotion of children's right to participate in ECE}

Among the few studies addressing teachers' practices towards the promotion of children's participation (Correia, Camilo, Aguiar, \& Amaro, 2019), some noted the importance of teacher-child interactions. Specifically, there is evidence suggesting the importance of teachers' sensitivity (e.g., Freitas Luís, Andrade, \& Santos, 2015; Mesquita-Pires, 2012; Pettersson, 2015; Salminen, 2013), active listening, reinforcement of children's talk (Alasuutari, 2014; Theobald \& Kultti, 2012; Tholin \& Jansen, 2012), and stimulation of discussions based on common rules and effective classroom management (Salminen, 2013). Presentations of children's work (Knauf, 2017; Pettersson, 2015) or children's participation in the resolution of peer disputes (MashfordScott \& Church, 2011) are also examples of practices to promote children's voice and expression of interests. In addition, free play (Freitas Luís et al., 2015) and active experiences (Nah \& Lee, 2016) are also described as favouring children's participation.

Practices limiting children's participation in ECE reflect teachers' greater agentic status and power imbalances in teacher-child interactions (e.g., Alasuutari, 2014; Mashford-Scott \& Church, 2011; Pettersson, 2015; Salminen, 2013). Importantly, extant research on teachers' motivating styles, from highly controlling to highly autonomy-supportive, describes them as potential predictors of teachers' sensitiveness, and consequently of the promotion of children's initiative and participation (Reeve, 2009).

Variations in ECE process quality (e.g., from warm and responsive, to more distant and controlling teacher-child interactions) seem to be associated with unequal conditions for children's participation (Bae, 2012). Specifically, teachers in high-quality ECE settings focus more on children's voices and initiatives, and promote more opportunities for children's participation (e.g., Freitas Luís et al., 2015; Houen, Danby, Farrell, \& Thorpe, 2016; Sheridan \& Samuelsson, 2001). Further, practices predominantly characterized by decision making by the adult, restricting children's participation, seem to be negatively associated with observed process quality (Lopes, Correia, \& Aguiar, 2016).

\subsection{Children' perceptions about their right to participate in ECE}

Encouraging children's voices and being attuned to their experiences may enhance children's engagement and capacities to contribute to decision making processes (Harris, Spina, Ehrich, \& Smeed, 2013), while fostering their agency and wellbeing (Hart \& Brando, 2018). Previous studies with older children (i.e., aged 11-14 years old) suggested that children reporting higher levels of perceived participation had better subjective wellbeing (Casas, Bello, González, \& Aligué, 2013), particularly regarding social relations and autonomy (Lloyd \& Emerson, 2017). In ECE, positive associations between children's perceived participation and their subjective wellbeing were reported in one study, with children reporting liking and being happier in their classroom when experiencing participation (Sandseter \& Seland, 2016). Importantly, participatory classrooms are perceived by children as those in which they can freely engage with and use different areas and materials without having to ask for ECE staff's approval, or as those 
where they may refuse staff proposals (Sandseter \& Seland, 2016). Also, they are perceived as the one's children like the most and in which they expect to have more opportunities to make choices, feel better, and have more fun (Correia \& Aguiar, 2017).

Existing research, though scarce, suggests that features of ECE settings, such as an enabling environment (i.e., valuing children's motivations and interests), and the extent to which teachers support and promote participation, shape children's perceptions of participation (e.g., Oliveira-Formosinho \& Lino, 2008; Smith, 2002). For instance, children describe education settings based on the features of their teachers, from stricter and focused on maintaining order, to more sensitive and autonomy supportive (Oliveira-Formosinho \& Lino, 2008). Moreover, one study described variations in children's perceptions as a function of ECE process quality (Sheridan \& Samuelsson, 2001). Specifically, children in high-quality settings reported to a larger extent that they were listened to and that teachers knew what they liked to do (Sheridan \& Samuelsson, 2001), reporting more opportunities to participate and exert influence (Sheridan, 2007).

Previous research has reported gender effects on school-aged (i.e., 10 and 11 years old) children's ideas, with girls reporting more positive perceptions of their participation rights than boys (Lloyd \& Emerson, 2017). However, the few studies involving preschool-aged children did not find gender or age differences (Correia \& Aguiar, 2017). Importantly, empirical evidence on children's ideas and experiences related to participation in ECE is still scarce (e.g., Correia \& Aguiar, 2017; Sheridan \& Samuelsson, 2001).

\subsection{The Portuguese context: Policies about children's right to participate in} ECE

Portugal ratified the CRC in 1990. Since then, several efforts were made, at the legal, political, and practical level, towards the promotion of children's rights, including children's right to participate (Araújo \& Fernandes, 2016). Specifically, over the last 30 years, extensive investments were made in ECE (Abreu-Lima, Leal, Cadima, \& Gamelas, 2013), which is currently available from age 3 until the age of compulsory education (i.e., 6 years by September 15th) (Law No. 4/97). Although ECE is optional, universal access is mandated from the age of 4 (Law No. 65/2015). Consequently, as in most high-income countries, ECE enrollment in Portugal currently exceeds 90\% (OECD, 2018; UNICEF, 2019). Specifically, coverage rates are $82.8 \%, 93.1 \%$, and $94 \%$ for 3, 4 and 5-year-olds, respectively (Direção-Geral de Estatísticas da Educação e Ciência, 2019).

ECE provision in Portugal is under the supervision of the Ministry of Education and encompasses public, private for-profit, and private nonprofit centers. In the school year of $2017 / 2018,53.1 \%$ of children attending preschool in Portugal were enrolled in public settings, $30.7 \%$ were enrolled in private non-profit settings, and $16.2 \%$ were enrolled in for-profit settings (Direção-Geral de Estatísticas da Educação e Ciência, 2018). Children normally attend ECE centres for a minimum of $5 \mathrm{~h}$ per day, five days a week, which corresponds to the free educational component in public and private non-profit centres. Importantly, the minimum qualification required to be an ECE teacher is a Masters' degree (European Commission/EACEA/Eurydice, 2019).

The Portuguese Curriculum Guidelines for Preschool Education (Lopes Da Silva, Marques, Mata, \& Rosa, 2016), which support teachers across the national ECE network, explicitly recognize children as subjects and agents within the educational process, stating the need to listen to them, taking their perspectives seriously, and ensuring their participation in decisions pertaining to them (e.g., planning, evaluation). Similarly, existing legal documents such as the Framework Law for Preschool Education (Law No. 4/97), the specific (Decree-Law No. 241, 2001), and the general profile of ECE teachers in Portugal (DecreeLaw No. 240, 2001) recommend the promotion of children's active participation, for instance in the development and implementation of shared rules, within a framework of democratic citizenship.
Recently, Portugal ranked second on the Kids Rights Index 2019 (Kids Rights Foundation, 2019), which considers the right to life, health, education, protection, and an enabling environment for children's rights (e.g., including respect for children's views and children's participation). Nonetheless, the European Commission (2013) has pointed to the lack of visibility and awareness of participation rights in several countries, including Portugal (Eurochild, 2015). In addition, existing studies have suggested low to moderate (Aguiar, Aguiar, Cadima, Correia, \& Fialho, 2019; Pinto, Pessanha, \& Aguiar, 2013) mean levels of quality in Portuguese ECE settings. These levels might prevent Portuguese ECE classrooms from positively impacting children's development (Abreu-Lima et al., 2013), and given the proposed associations between ECE quality and child participation (Sheridan \& Samuelsson, 2001; Sheridan, 2007), they might also compromise the implementation of this right.

\subsection{The current study}

In a recent study, we investigated ECE teachers' ideas about children's right to participate, and identified four groups of teachers: (1) a group of teachers focusing on Teachers' Motivation (Type 1), referred to participation as depending on teachers' action and motivation; (2) a group of teachers focusing on Teachers' Conditioned Responsibility (Type 2), considered participation as a function of teachers' responsibility, but also as a function of children's benefits and child-related obstacles; (3) a group of teachers focusing on Children's Benefits (Type 3), emphasized specific individual benefits for children; and (4) a group of teachers saw participation as Context Dependent (Type 4), focusing on the contextual constraints and obstacles to children's participation (Correia, Carvalho, \& Aguiar, 2019). Generally, these profiles reflected distinct elements of participatory interactions: teachers (i.e., Teachers' Motivation), children (i.e., Children's Benefits), and the context (i.e., Context Dependent). In the current study, we analysed the associations between these four profiles of ECE teachers' ideas and young children's perceived participation in centre-based ECE settings. Further, we investigated if these associations were mediated by teachers' practices, including observed participation practices and classroom process quality.

By pursuing these goals, we addressed multiple gaps in the scarce literature on children's right to participate in ECE. For instance, we focused on children's perceived participation as an outcome, answering the call for more research considering children's perspectives (James, 2007). Moreover, to our knowledge, no study has addressed both teachers' ideas and children's perceived participation, nor investigated associations between them. Importantly, no studies have examined the associations between participation practices, classroom process quality, and children's perceived participation (Lansdown, 2010). Most studies have relied on a single level of analyses, focusing mostly on ECE teachers' ideas about children's right to participate and far less on observed practices, with very few studies examining both (Nah \& Lee, 2016; Thornberg \& Elvstrand, 2012). Therefore, we extend existing research by considering both ideas and practices, teacher and child reports, as well as self-reported and observed practices.

We expected ECE teachers' profiles of ideas regarding children's right to participate to be directly associated with children's perceived participation in their classroom (H1). We also expected the associations between teachers' profiles and children's perceived participation to be mediated by teachers' reports of practices promoting children's participation (H2). Further, we expected a positive association between ECE teachers' reports of participation practices, and children's perceived participation (H3), mediated by independent observations of participation practices (H4). We also expected that process quality mediated the association between ECE teachers' reports of participation practices, and children's perceived participation (H5). Hypotheses are schematized in Fig. 1. 

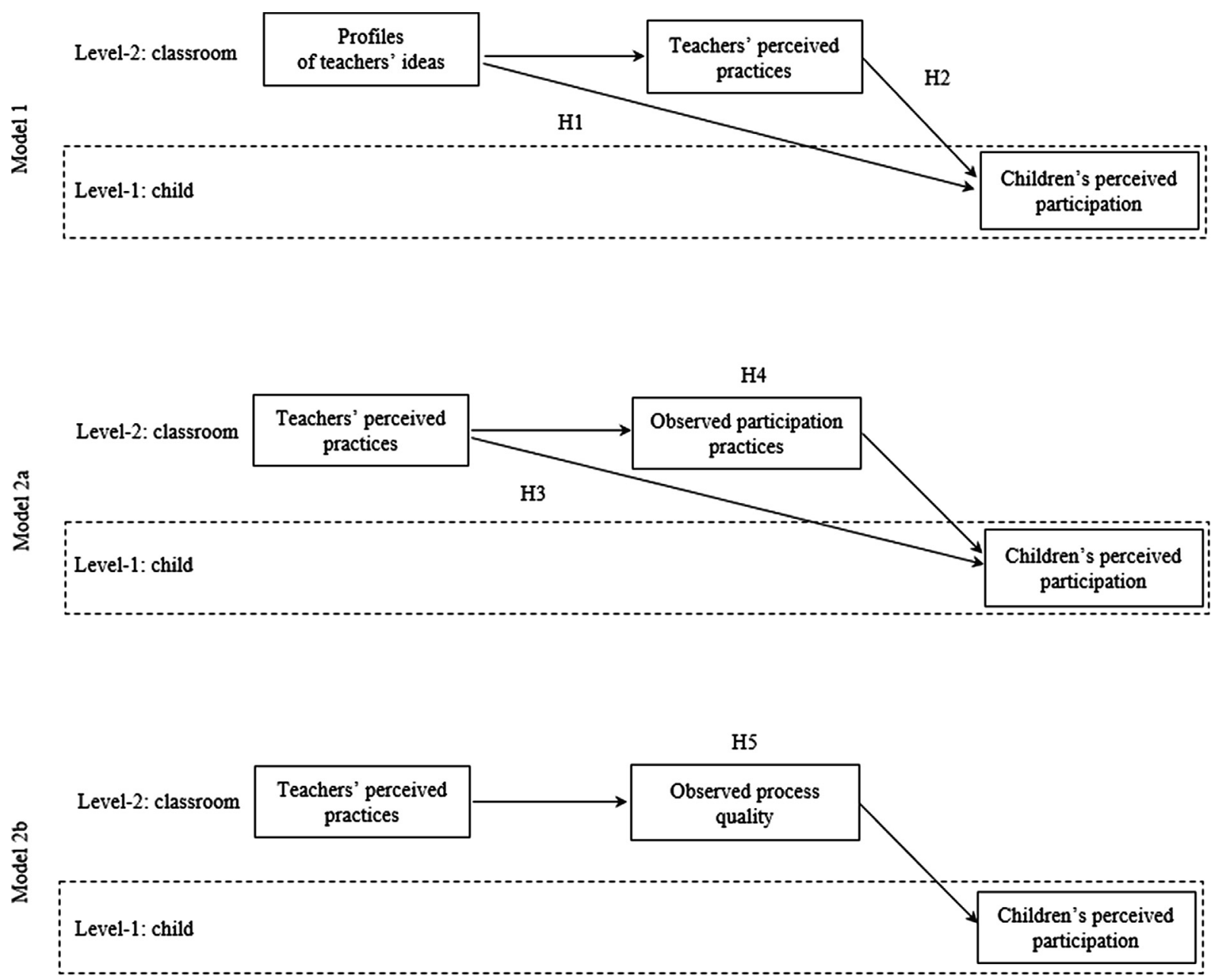

Fig. 1. Hypothesized associations among variables.

\section{Method}

\subsection{Participants}

Participants were 336 children (163 boys), aged between 44 and 84 months $(M=63.74, S D=8.05)$. Mothers' education varied considerably: $58.0 \%$ had a university degree, $18.8 \%$ completed highschool, and $20.8 \%$ did not complete high-school (i.e., had less than 12 years of schooling). Information was missing for $2.4 \%$ of mothers.

Participants also included 58 ECE teachers (all female), aged between 26 and 60 years old $(M=43.07, S D=8.58)$, with professional experience ranging between 2 and 39 years $(M=19, S D=8.36)$. Teachers were responsible for groups with 8 to 27 children $(M=20.79$, $S D=4.21$ ), with $75.9 \%$ of participating classrooms serving mixed-aged groups (i.e., children from 3 to 6 years old), which is consistent with the national landscape (Abreu-Lima et al., 2013). All teachers had at least a higher-education degree in early childhood education or equivalent, with $12.1 \%$ holding a Masters' degree. Nearly a third (19.0\%) had a specialization course (e.g., early childhood intervention, special education, Waldorf pedagogy).

Participating teachers were responsible for 58 ECE classrooms from 24 randomly selected ECE centres located in the metropolitan area of Lisbon (AML, 2019). This area, which corresponds to $36.7 \%$ of the Portuguese population (Pinto et al., 2013), is classified as a 'non-interior' or littoral territory, composed of urban and semi-urban areas (Conselho Nacional de Educação, 2018). Classrooms were predominantly from the public sector $(48.3 \%)$, but also from private forprofit centres $(27.6 \%)$ and private non-profit centres (24.1\%). The type of institution followed the population distribution, $\chi^{2}(2)=4.38$, $p=.115, N=58$.

\subsection{Measures}

\subsubsection{Teachers' ideas about children's right to participate}

We assessed teachers' multidimensional ideas about children's right to participate (i.e., conceptions, practices, conditions, obstacles, and potential benefits) with an interview specifically designed for the purpose (see Correia, Carvalho, \& Aguiar, 2019). After content analysis, a multiple correspondence analysis was used to identify profiles of teachers' ideas and then a cluster analysis allowed us to group teachers according to their profiles: Teachers' Motivation (Type 1, 34.5\%), Teachers' Conditioned Responsibility (Type 2, 22.4\%), Children's Benefits (Type 3, 19.0\%), and Context Dependent (Type 4, 24.1\%) (see Correia, Carvalho, \& Aguiar, 2019). Teacher profile was used as a categorical predictor (see Fig. 2).

\subsubsection{Teachers' perceived participation practices}

We assessed teachers' perceptions of their practices to promote children's participation with the Teachers' Perceived Participation Practices Scale (TPPP), composed of 26 items rated on a 5-point scale ( $1=$ not typical to $5=$ extremely typical). An exploratory factor analysis (EFA, principal components) was conducted with varimax rotation to identify the factorial structure. Kaiser criterion and parallel analysis (Costello \& Osborne, 2005; O'Connor, 2000) converged in a two-factor solution. As described in Table 1, the two factors obtained were Children's Expression and Responsibility (12 items; factor loadings between 


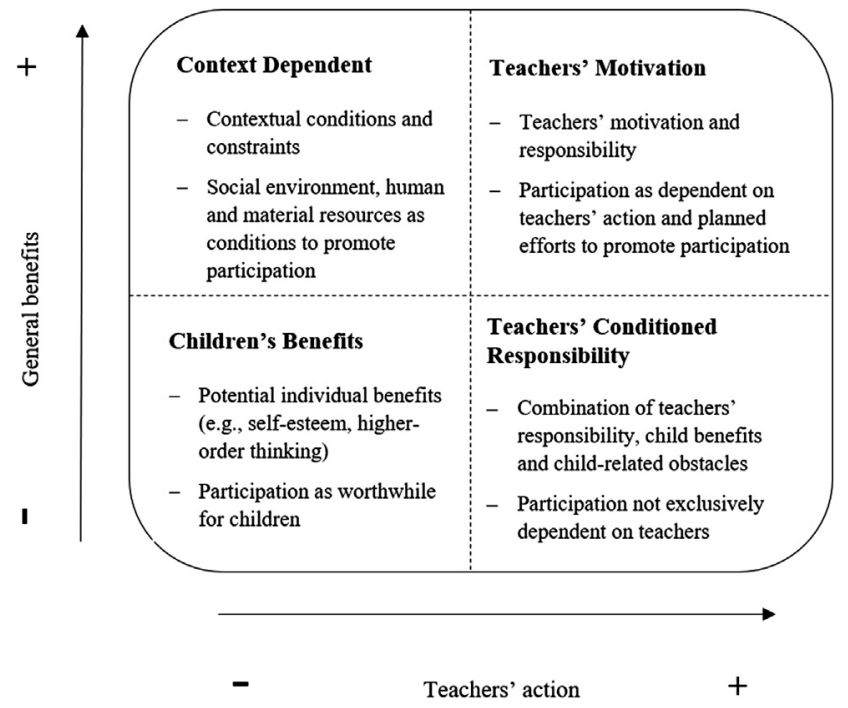

Fig. 2. Profiles of teachers' ideas about children's right to participate in ECE.

0.48 and 0.78 ), referring to teachers' practices contributing to the implementation of children's participation, and Decision Making by the Adult (six items; factor loadings between 0.62 and 0.79), reflecting teacher practices restricting children's participation. Both factors presented good internal consistency ( $\alpha$ Children's Expression and Responsibility $=.84 ; \alpha$ Decision Making by the Adult $=.78$ ) and were moderately correlated $(r=-.31)$ (Cohen, 1992).

\subsubsection{Observed teachers' participation practices}

We assessed teachers' implementation of participation practices, with the Observed Teachers' Participation Practices Scale (OTPP), an observation measure composed of 13 items rated on a 5-point scale $(1=$ not typical to 5 = extremely typical). An EFA (principal components and varimax rotation) was conducted to identify the factorial structure, resulting in 10 items organised in two factors (informed by the Kaiser criterion and a parallel analysis). Three items (i.e., "Children have the opportunity to express their ideas, opinions, and personal experiences", "Most of the materials exhibited were elaborated by children", "The teacher changes his/her plans to develop activities related to children's interests") were dropped due to cross loadings. As described in Table 2, the two factors obtained were Observed Children's Choice (5 items; factor loadings between .62 and $.93, \alpha=.92$ ), reflecting observed practices to promote children's choice and initiative and Observed Conditions for Participation ( 5 items; factor loadings between .55 and $.78 ; \alpha=.74)$, referring to conditions enhancing participation.

\subsubsection{Observed process quality}

We assessed classroom process quality with the Classroom Assessment Scoring System, Pre-K version (CLASS; Pianta, LaParo, \& Hamre, 2008). The CLASS comprises 10 dimensions, coded on a 7-point scale (1-2 = low quality, 3-5 = middle quality, and 6-7 = high quality). A confirmatory factorial analysis (CFA) was used to confirm the factorial structure. Given the item-level ordered categorical data, a robust estimation method was chosen - the diagonal weighted least squares (DWLS) (Muthén \& Satorra, 1995). The three-factor model supported the original structure, providing a good model fit (Hu \& Bentler, 1999; Kline, 2011): $\chi^{2}(32)=69.219, p<.001 ; \chi^{2} / \mathrm{df}=2.163$; CFI $=0.98$; $\mathrm{TLI}=0.97$; RMSEA $=0.14$; and SRMR $=0.11$ ). Although RMSEA and SRMR were relatively high, this was likely due to the small sample size, as reported by Kenny et al., 2015 for $N \leq 100$. Nevertheless, the results of the most commonly reported fit indices validated the quality of the CFA solution. CLASS is organised in three domains: Emotional Support ( $\alpha=0.88$ ) comprises the dimensions Positive climate, Negative climate (reversed), Teacher sensitivity, and Regard for student perspectives (standardized factor loadings between .78 and .98); Classroom Organization $(\alpha=.60$, and mean inter-item correlation $=.35$, within the recommended range .15 - .50; Clark \& Watson, 1995) includes the dimensions Behaviour management, Productivity, and Instructional learning formats (standardized factor loadings between .50 and .62); and Instructional Support $(\alpha=.84)$ includes the dimensions Concept development, Quality of feedback, and Language modelling (standardized factor loadings between .67 and .96).

\subsubsection{Children's perceived participation}

We assessed children's ideas about their own right to participate with "Choosing classrooms: A structured interview on children's right to participate", an interview protocol involving the presentation of two illustrative images and narratives (i.e., participation and non-participation) (see Correia \& Aguiar, 2017). In this study, we used three questions specifically aiming to assess children's perceptions about their participation, by eliciting comparisons with the child's own classroom ("which classroom is most similar to yours?"), own teacher ("which teacher is most similar to yours?"), and asking about the child's

Table 1

Factor Loadings for Exploratory Factor Analysis of Two Components of Teachers' Perceived Participation Practices $(N=58)$.

\begin{tabular}{|c|c|c|}
\hline In my classroom... & Children's Expression and Responsibility & Decision Making by the Adult \\
\hline I include children's interests and ideas in my goals and planning & .776 & -.046 \\
\hline I create daily opportunities for children to express their ideas and opinions & .758 & -.017 \\
\hline Children participate in the evaluation of our work & .705 & -.037 \\
\hline I provide daily opportunities for children to share their personal experiences during group activities & .661 & -.058 \\
\hline Rules for common life are set with the children & .613 & -.141 \\
\hline Children are responsible for daily tasks needed for collective life & .585 & .009 \\
\hline Children make proposals of activities and play to the adults & .585 & -.280 \\
\hline Children participate in the definition of classroom tasks & .551 & -.054 \\
\hline Children choose their play & .545 & -.297 \\
\hline Children have freedom of movement and may decide where to play/work & .509 & -.249 \\
\hline Problems are debated in group, so that children find their own solutions & .490 & -.018 \\
\hline Children are responsible for documenting the activities they choose & .482 & -.333 \\
\hline I define the activity plan to ensure that my goals for the group are met & -.206 & .786 \\
\hline I set the rules that children must follow & -.078 & .710 \\
\hline I decide how areas and materials are organized, based on classroom space and my goals for the group & .030 & .659 \\
\hline All children to the same work, with the same materials & -.235 & .641 \\
\hline The schedule is set by me or the center coordination and children know they must comply & .124 & .639 \\
\hline Children participate in decision-making about the center's organization/dynamics (reverse) & -.294 & .617 \\
\hline Eigenvalues & 4.079 & 3.126 \\
\hline Explained variance (\%) & 26.160 & 17.367 \\
\hline
\end{tabular}

Note. Principal component analysis with varimax rotation. Factor loadings $\geq 0.50$ are in bold. 
Table 2

Factor Loadings for Exploratory Factor Analysis of Two Components of Teachers' Observed Participation Practices $(N=58)$.

\begin{tabular}{|c|c|c|}
\hline In this classroom... & Observed Children's Choice & Observed Conditions for Participation \\
\hline Children choose activities and play in which they want to participate & .930 & .163 \\
\hline Children have freedom of movement and may decide where to play/work & .929 & .171 \\
\hline Children choose the peers with whom they want to play & .888 & .057 \\
\hline Children choose the materials they use in the activities & .829 & .261 \\
\hline Children make proposals of activities and play to the adults & .618 & .415 \\
\hline Problems are debated in group, so that children find their own solutions & .115 & .777 \\
\hline $\begin{array}{l}\text { Materials in the classroom are diverse (i.e., each child's work is individualized, with materials and } \\
\text { elements chosen by the child) }\end{array}$ & .279 & .754 \\
\hline Exposed works and materials are at the child level and reach & .289 & .680 \\
\hline $\begin{array}{l}\text { Children are responsible for daily tasks needed for collective life (e.g., feeding a pet, documenting } \\
\text { attendance) }\end{array}$ & .188 & .653 \\
\hline Children are responsible for documenting the activities they choose & -.010 & .554 \\
\hline Eigenvalues & 3.797 & 2.668 \\
\hline Explained variance (\%) & 37.971 & 26.684 \\
\hline
\end{tabular}

Note. Principal component analysis with varimax rotation. Factor loadings $>0.50$ are in bold.

opportunities to participate during that day ("what did you do, and who decided/chose?"). Answers were coded in terms of absence vs. presence $(0=$ non-participation, $1=$ participation $)$, and a new variable that counted the number of participation responses, ranging from 0 to 3, was computed.

\subsection{Procedure}

This study was conducted within a broader research project, "Children's right to participate in early childhood education: From rights to empirical evidence". The project was approved by the National Data Protection Commission and the Institutional Review Board at ISCTE-IUL. Recruitment and data collection were conducted during the 2015/2016 and 2016/2017 school years (i.e., approximately half during the first year, and the other half during the second). All ECE settings were randomly selected from existing public databases. In total, 170 ECE settings (i.e., school boards) of the metropolitan area of Lisbon were contacted, trying to assure representativeness of the different ECE types of settings in Portugal (Direção-Geral de Estatísticas da Educação e Ciência, 2019). A response rate of $19.4 \%$ was achieved, resulting in meetings with 33 ECE settings (i.e., 11 public, 13 private for-profit, and 9 private non-profit) to provide information about project aims and procedures. From these, we obtained a participation rate of $72.7 \%$, resulting in data collection in 58 ECE classrooms from 24 ECE settings. In each classroom, ECE teachers and the parents of all child participants signed informed consent forms. All participating children provided verbal assent.

Teacher interviews (for interview protocol see Correia, Carvalho, \& Aguiar, 2019) were conducted individually in a designated room, in the ECE setting, between November and January. Interviews were conducted by the first and third authors, as well as a research assistant. All three had a Masters' degree in Psychology or Social Sciences. Teachers' reports of participation practices, observed participation practices, and observed process quality, as well as children's perceived participation were collected between February and June.

In each classroom, six typically developing children were randomly selected, based on age and gender. The aim was to interview three boys and three girls in each classroom (i.e., to ensure gender balance), aged preferably 4 to 6 years-old (i.e., to increase the validity of sociometric data not used for the purposes of this study), although it was not possible to strictly follow these criteria in all classrooms. Children's interviews were conducted individually by the first and third authors, in a private room in the ECE setting, lasting from 15 to $20 \mathrm{~min}$.

Observations of participation practices were conducted by two observers (i.e., the first and third authors) during a typical morning (i.e., approximately $2 \mathrm{hrs}$ ). Reliability checks were performed in $25 \%$ of classrooms, resulting in Intraclass Correlation Coefficients (ICCs; two- way mixed-effects model, single measures, consistency) of 0.61 (Observed Conditions for Participation) and 0.70 (Observed Children's Choice). Mean interrater percent agreement within-1 point was $92.0 \%$ for Observed Conditions for Participation, and $92.0 \%$ for Observed Children's Choice. Process quality observations took place during the same morning, by the first and third authors, who were certified CLASS Pre-K observers. In each classroom, four observation cycles were conducted, each lasting about $30 \mathrm{~min}$ (i.e., $20 \mathrm{~min}$ of coding, followed by 10 min of scoring). For each dimension, the mean score across the four cycles was calculated and computed. In addition, the two certified observers responsible for all observations also conducted reliability checks in $25 \%$ of classrooms, resulting in ICCs (two-way mixed-effects model, single measures, consistency) ranging from 0.34 (Instructional Support) to 0.75 (Emotional Support). Mean interrater percent agreement within-1 point was $97.0 \%$ for Emotional Support, $94.0 \%$ for Classroom Organization, and $100.0 \%$ for Instructional Support.

\subsection{Data analysis}

We first computed descriptive statistics and measures of association (eta coefficient and Person's correlation) among study variables. To test our hypotheses, we used multilevel modelling as our data had a hierarchical structure: children nested in classrooms (Hox, 2010; Snijders \& Bosker, 2003). We used mixed-effects models to test the upper level mediation $(2 \rightarrow 2 \rightarrow 1)$, since the effect of Level-2 predictors on Level-1 outcomes was mediated by Level-2 mediators (Bauer, Preacher, \& Gil, 2006). Given that all the mediator models included multiple parallel mediators (Preacher \& Hayes, 2008), multicollinearity was also checked. To test indirect effects, parametric bootstrapping was used to create confidence intervals (CIs) in $R$ (Preacher \& Selig, 2012). As the profiles of teachers' ideas were coded as a categorical variable, dummy coding was used to examine the comparisons between the four categories and, therefore, several multiple regressions were conducted, sequentially alternating the reference category.

\section{Results}

\subsection{Descriptive statistics and associations}

Means, standard deviations, and associations among study variables are presented in Table 3. Correlations ranged from small to large (Cohen, 1992) and were consistent with our hypotheses. For instance, Children's Perceived Participation was positively correlated with observed Emotional Support, and with Observed Children's Choice, and negatively correlated with teacher reports of Decision Making by the Adult. No associations were found between Children's Perceived Participation and their age or gender. Therefore, age and gender were not 
Table 3

Descriptive Statistics and Associations among Variables.

\begin{tabular}{|c|c|c|c|c|c|c|c|c|c|c|}
\hline Variables & $M$ & $S D$ & 3 & 4 & 5 & 6 & 7 & 8 & 9 & 10 \\
\hline \multicolumn{11}{|l|}{ Child level $(N=336)$} \\
\hline 1. Sex (1 = boys) & .485 & - & .06 & & & & & & & \\
\hline 2. Chronological age (months) & 63.7 & 8.05 & -.02 & & & & & & & \\
\hline 3. Chilldren's Perceived Participation & 1.77 & 1.02 & & & & & & & & \\
\hline \multicolumn{11}{|l|}{ Classroom level $(N=58)$} \\
\hline 4. Profiles of teachers' ideas & - & - & .11 & - & & & & & & \\
\hline 5. Emotional Support & 4.64 & 0.76 & $.18^{*}$ & .14 & & & & & & \\
\hline 6. Classroom Organization & 4.98 & 0.71 & .07 & .38 & $.62^{*}$ & & & & & \\
\hline 7. Instructional Support & 1.51 & 0.36 & -.08 & .21 & .04 & $.28^{*}$ & & & & \\
\hline 8. Children's Expression and Responsibility & 4.14 & 0.50 & .05 & .16 & $.19^{*}$ & $.25^{*}$ & -.10 & & & \\
\hline 9. Decision Making by the Adult & 3.37 & 0.75 & $-.18^{*}$ & .23 & $-.26^{*}$ & $-.26^{*}$ & -.11 & $-.37^{*}$ & & \\
\hline 10. Observed Children's Choice & 3.19 & 1.11 & $.26^{*}$ & .11 & $.55^{*}$ & $.35^{*}$ & $-.22 *$ & $.18^{*}$ & $-.37^{*}$ & \\
\hline 11. Observed Conditions for Participation & 2.25 & 0.79 & .08 & .14 & $.35^{*}$ & $.36^{*}$ & .02 & $.45^{*}$ & $-.41^{*}$ & $.47^{*}$ \\
\hline
\end{tabular}

Note. Eta coefficient was reported for the association between profiles (categorical variable) and other quantitative variables.

Sex - proportion of boys was reported.

$* p<.01$.

included in subsequent models for parsimony.

\subsection{Profiles of teachers' ideas and children's perceived participation: The mediating role of perceived participation practices}

To evaluate the suitability of multilevel models, the intraclass correlation coefficient (ICC) was calculated. The results showed that $15.4 \%$ of the variance in Children's Perceived Participation was explained at the classroom level and, therefore, a multilevel approach was warranted. Fig. 3 shows the results of Model 1, which examined teachers' reports of participation practices as mediators of the association between teacher profiles and Children's Perceived Participation, thus testing $\mathrm{H} 1$ and $\mathrm{H} 2$. As the mediator models included multiple parallel mediators, multicollinearity was verified. Tolerance values ranged between 0.53 and 0.99 ; thus, there were no problems with multicollinearity (Hair, Anderson, Tatham, \& Black, 2010).

To compare the four categories of the Profiles of Teachers' Ideas, several multiple regressions were conducted, sequentially alternating the reference category. However, we only reported the two significant comparisons (see Fig. 3). The profile focusing on Children's Benefits significantly differed from the profiles focusing on Teachers' Motivation and Teachers' Conditioned Responsibility, presenting a lower mean on the mediator Decision Making by the Adult, $M_{\text {dif }}=-0.326, t=-2.839$, $p=.005 ; M_{\mathrm{dif}}=-0.526, t=-4.255, p<.001$, respectively. The effect of Decision Making by the Adult on Children's Perceived Participation was negative ( $B=-0.234, t=-2.212, p=.032$ ). A mediating effect of perceived Decision Making by the Adult was found between the comparison of Children's Benefits with Teachers' Motivation and the outcome Children's Perceived Participation, as the relative indirect effect was significant, $B=0.079$, Boot $95 \%$ CI $=0.016,0.168$. Since the relative direct effect was not significant ( $p>.05$ ), results reveal full mediation. Therefore, teachers' profiles were associated with Children's
Perceived Participation through teachers' perceived Decision Making by the Adult, but only for the comparison between the profile focusing on Children's Benefits and the profile focusing on Teachers' Motivation.

\subsection{Teachers' reports of participation practices and children's perceived} participation: The mediating role of observed participation practices

Table 4 presents the results of Model 2a which examined the mediating role of observed participation practices in the association between teachers' perceived practices and Children's Perceived Participation (see also Fig. 4), thus testing $\mathrm{H} 3$ and $\mathrm{H} 4$.

Decision Making by the Adult had a significant effect on the mediator Observed Children's Choice $(B=-0.529, t=-6.460, p<.001)$. In turn, this mediator had a significant effect on Children's Perceived Participation $(B=0.228, t=4.093, p<.001)$. We found a mediation effect of Observed Children's Choice on the association between Decision Making by the Adult and Children's Perceived Participation, with a significant indirect effect $(B=-0.121$, Boot $95 \%$ CI $=-0.195$, -0.059). The direct effect of Decision Making by the Adult on Children's Perceived Participation was not significant $(p>.05)$, therefore there was a full mediation of Observed Children's Choice.

Table 5 shows the results of Model $2 \mathrm{~b}$, which tested the mediating role of process quality between ECE teachers' perceived practices and children's perceived participation (H5). Only one significant mediation was found (see also Fig. 5).

Specifically, we found a mediating effect of Emotional Support in the association between Decision Making by the Adult and Children's Perceived Participation, with a significant indirect effect $(B=-0.054$, Boot $95 \% \mathrm{CI}=-0.106,-0.015)$. The direct, negative effect of Decision Making by the Adult on Children's Perceived Participation remained significant ( $\mathrm{B}=-0.227, t=-2.247, p=.029$ ) when the mediator was present, suggesting a partial mediation.

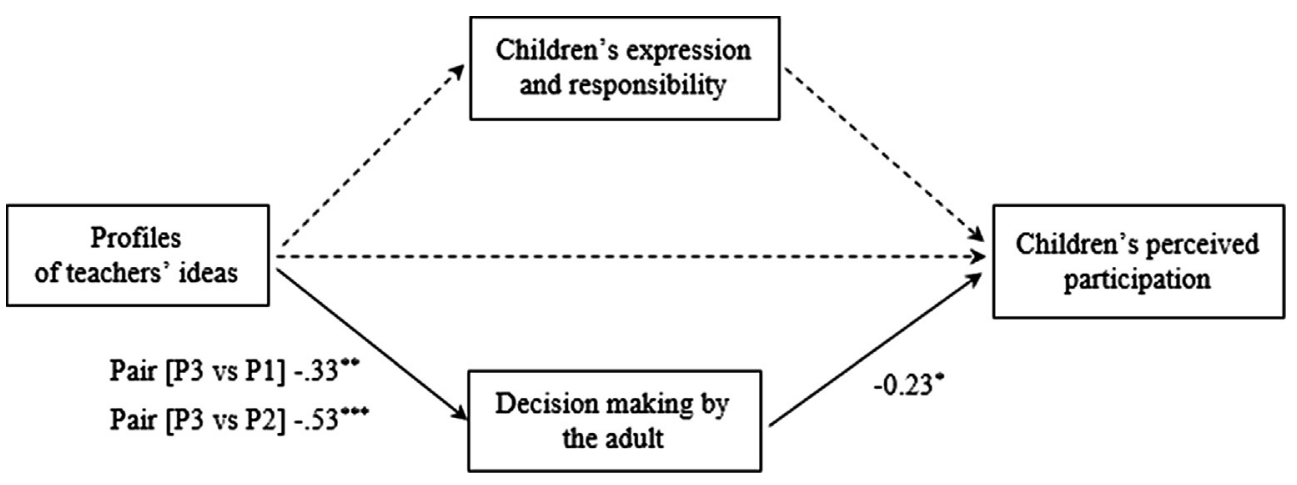

Fig. 3. Model examining teachers' perceived participation practices as mediators of the relationship between their ideas about children's right to participate, and Children's Perceived Participation in the ECE setting. P1 = Teachers' Motivation; P2 = Teachers' Conditioned Responsibility; P3 = Children's Benefits. Dashed arrows refer to non-significant effects. Solid arrows refer to significant effects. P1 was the reference category in the pair [P3 vs P1] and P2 was the reference category in the pair [P3 vs P2]. ${ }^{*} p<.05 .{ }^{* *} p<.01 .{ }^{* * *} p<.001$. 
Table 4

Hierarchical Linear Regression of Mediation Model with Observed Participation Practices.

\begin{tabular}{|c|c|c|c|c|c|c|c|c|c|}
\hline \multirow[t]{2}{*}{ Variables } & \multicolumn{3}{|c|}{ Observed Children's Choice } & \multicolumn{3}{|c|}{ Observed Conditions for Participation } & \multicolumn{3}{|c|}{ Children's Perceived Participation } \\
\hline & Coef. & SE & $95 \% \mathrm{CI}$ & Coef. & SE & $95 \% \mathrm{CI}$ & Coef. & SE & $95 \% \mathrm{CI}$ \\
\hline \multicolumn{10}{|l|}{ Total effect } \\
\hline Intercept & & & & & & & $2.69^{k * *}$ & 0.82 & $1.04,4.33$ \\
\hline Children's Expression and Responsibility & & & & & & & -0.02 & 0.15 & $-0.33,0.28$ \\
\hline Decision Making by the Adult & & & & & & & -0.24 & 0.10 & $-0.44,0.04$ \\
\hline Level-1 variance & & & & & & & $0.88^{* \cdots * * x}$ & 0.07 & $0.74,1.04$ \\
\hline Level-2 variance & & & & & & & $0.13^{*}$ & 0.06 & $0.06,0.31$ \\
\hline \multicolumn{10}{|l|}{ Direct effect } \\
\hline Intercept & $4.47^{* * * *}$ & 0.66 & $3.17,5.78$ & $1.01^{*}$ & 0.43 & $0.17,1.85$ & $1.79^{*}$ & 0.81 & $1.70,3.41$ \\
\hline Children's Expression and Responsibility & 0.12 & 0.12 & $-0.12,0.37$ & $0.54^{* * * * *}$ & 0.08 & $0.39,0.70$ & 0.01 & 0.15 & $-0.29,0.31$ \\
\hline Decision Making by the Adult & $-0.53^{* \ldots \times k}$ & 0.08 & $-0.69,-0.37$ & $-0.30^{* * * * x}$ & 0.05 & $-0.40,-0.19$ & -0.16 & 0.10 & $-0.36,0.05$ \\
\hline Observed Children's Choice & & & & & & & $0.23^{* * *}$ & 0.07 & $0.10,0.37$ \\
\hline Observed Conditions for Participation & & & & & & & -0.12 & 0.10 & $-0.33,0.09$ \\
\hline Level-1 variance & & & & & & & $0.88^{* * \ldots * *}$ & 0.07 & $0.74,1.04$ \\
\hline Level-2 variance & & & & & & & $0.09^{*}$ & 0.05 & $0.03,0.26$ \\
\hline Pseudo $\mathrm{R}^{2}$ & 0.14 & & & 0.27 & & & 0.08 & & \\
\hline \multicolumn{10}{|c|}{ Indirect effect for Children's Expression and Responsibility } \\
\hline By Observed Children's Choice & & & & & & & 0.03 & 0.04 & $-0.04,0.10$ \\
\hline By Observed Conditions for Participation & & & & & & & -0.06 & 0.05 & $-0.16,0.03$ \\
\hline \multicolumn{10}{|l|}{ Indirect effect for Decision Making by the Adult } \\
\hline By Observed Children's Choice & & & & & & & -0.12 & 0.03 & $-0.20,-0.06$ \\
\hline By Observed Conditions for Participation & & & & & & & 0.03 & 0.03 & $-0.02,0.09$ \\
\hline
\end{tabular}

$* p<.05$.

$* * p<.01$.

$* * * p<.001$.

\section{Discussion}

In this study, we investigated the associations between ECE teachers' ideas about children's right to participate and children's perceived participation in centre-based ECE settings. Specifically, we examined how specific profiles of ECE teachers' ideas predicted children's perceived participation, through teachers' perceived participation practices. Furthermore, we investigated if the association between teachers' perceived participation practices and children's perceived participation was itself mediated by observed participation practices and observed process quality.

Our hypothesis that ECE teachers' ideas regarding children's right to participate would be directly associated with Children's Perceived Participation (H1), was not confirmed. Nonetheless, ECE teachers' ideas about participation were associated with Children's Perceived Participation, through the mediation of teachers' perceived practices (H2) related to Decision Making by the Adult, thus partially confirming our hypothesis. Specifically, teachers focusing on children's benefits, in comparison with teachers focusing on teachers' motivation, reported lower decision making by the teacher (i.e., restriction of children's participation), which in turn was associated with decreased participation, as reported by children. This finding is consistent with previous research suggesting that teachers' ideas, namely about children's participation (e.g., Nah \& Lee, 2016), are associated with what teachers do (or report doing) (e.g., Gates, 2006; Pajares, 1992). In effect, teachers' ideas seem to be filters and frames for interpreting child participation, but to understand them and what they represent, we need to relate them with practice (Fives \& Buehl, 2012; Pajares, 1992). It is also in line with studies showing that children tend to expect fewer opportunities to participate in classrooms characterized by non-participation practices (Correia \& Aguiar, 2017). This mediation effect illustrates a bioecological mechanism (Bronfenbrenner \& Morris, 2006) whereby teacher individual dispositions (i.e., belief systems) are associated with children's subjective experiences of participation, through the quality of proximal processes, that is, the level of reciprocity in classroom interactions, measured through teacher reports of Decision Making by the Adult.

On the differences between teacher profiles, we argue that teachers focusing on children's individual benefits from participation may value it as a means to pursue their mission to enhance children's development, which may strengthen their commitment to increase reciprocity in their relationships with children. In turn, teachers viewing children's participation as dependent on individual teachers' motivation and dispositions may perceive the promotion of children's participation as a

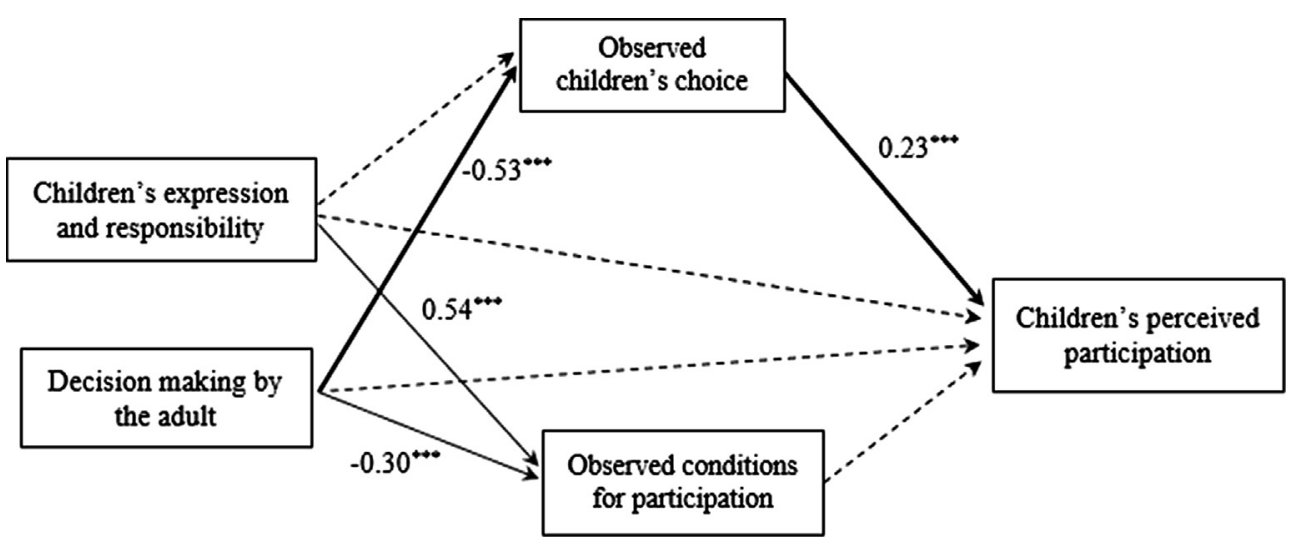

Fig. 4. Model examining observed participation practices as parallel multiple mediators of the relationship between teachers' perceptions of their participation practices, and Children's Perceived Participation in the ECE setting. Dashed arrows refer to nonsignificant effects. Solid arrows refer to significant effects. Solid bold arrows refer to significant mediating effect. ${ }^{* *} p<.01$. ${ }^{* * * *} p<.001$. 
Table 5

Hierarchical Linear Regression of Mediation Model with Domains of Observed Process Quality.

\begin{tabular}{|c|c|c|c|c|c|c|c|c|c|c|c|c|}
\hline \multirow[t]{2}{*}{ Variables } & \multicolumn{3}{|c|}{ Emotional Support } & \multicolumn{3}{|c|}{ Classroom Organization } & \multicolumn{3}{|c|}{ Instructional Support } & \multicolumn{3}{|c|}{ Children's Perceived Participation } \\
\hline & Coef. & SE & $95 \% \mathrm{CI}$ & Coef. & SE & $95 \% \mathrm{CI}$ & Coef. & SE & $95 \% \mathrm{CI}$ & Coef. & SE & $95 \% \mathrm{CI}$ \\
\hline \multicolumn{13}{|l|}{ Direct effect } \\
\hline Intercept & $4.73^{k \ldots \ldots *}$ & 0.46 & $3.83,5.64$ & $4.62^{k * k * k}$ & 0.40 & $3.83,5.41$ & $2.27^{* \ldots * k}$ & 0.22 & $1.83,2.71$ & $2.58^{*}$ & 1.01 & $0.56,4.60$ \\
\hline Children's Expression and Responsibility & 0.16 & 0.09 & $-0.01,0.33$ & $0.24^{* \ldots * k}$ & 0.07 & $0.09,0.38$ & $-0.12^{* \star *}$ & 0.04 & $\begin{array}{l}-0.20 \\
-0.04\end{array}$ & -0.08 & 0.15 & $-0.38,0.23$ \\
\hline Decision Making by the Adult & $-0.22^{* \ldots n k x}$ & 0.06 & $\begin{array}{l}-0.33 \\
-0.11\end{array}$ & $-0.18^{* * * *}$ & 0.05 & $\begin{array}{l}-0.27 \\
-0.08\end{array}$ & $-0.08^{* *}$ & 0.03 & $\begin{array}{l}-0.13 \\
-0.03\end{array}$ & $-0.23^{*}$ & 0.10 & $\begin{array}{l}-0.43 \\
-0.02\end{array}$ \\
\hline Emotional Support & & & & & & & & & & $0.25^{*}$ & 0.12 & $0.01,0.48$ \\
\hline Classroom Organization & & & & & & & & & & -0.10 & 0.14 & $-0.37,0.18$ \\
\hline Instructional Support & & & & & & & & & & -0.28 & 0.21 & $-0.69,0.14$ \\
\hline Level-1 variance & & & & & & & & & & 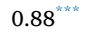 & 0.07 & $0.74,1.04$ \\
\hline Level-2 variance & & & & & & & & & & $0.11 *$ & 0.05 & $0.04,0.29$ \\
\hline Pseudo $\mathrm{R}^{2}$ & 0.08 & & & 0.10 & & & 0.04 & & & 0.07 & & \\
\hline \multicolumn{13}{|l|}{$\begin{array}{l}\text { Indirect effect for Children's Expression and } \\
\text { Responsibility }\end{array}$} \\
\hline By Emotional Support & & & & & & & & & & 0.04 & 0.03 & $-0.02,0.10$ \\
\hline By Classroom Organization & & & & & & & & & & -0.02 & 0.03 & $-0.07,0.04$ \\
\hline By Instructional Support & & & & & & & & & & 0.03 & 0.03 & $-0.04,0.10$ \\
\hline \multicolumn{13}{|l|}{$\begin{array}{l}\text { Indirect effect for Decision Making by the } \\
\text { Adult }\end{array}$} \\
\hline By Emotional Support & & & & & & & & & & -0.05 & 0.02 & $\begin{array}{l}-0.11 \\
-0.02\end{array}$ \\
\hline By Classroom Organization & & & & & & & & & & 0.01 & 0.02 & $-0.02,0.06$ \\
\hline By Instructional Support & & & & & & & & & & 0.02 & 0.01 & $-0.00,0.05$ \\
\hline
\end{tabular}

Note. As the model maintained the same predictors variables and the outcome variable, the total effect is the same already reported in Table 4.

$* p<.05$.

$* * p<.01$.

$* * * p<.001$.

discretionary feature of ECE teachers' roles and practices. With potential implications for our understanding of professionalism in ECE, these differences merit further investigation.

Importantly, our findings did not provide support for the mediating role of Children's Expression and Responsibility. With participating teachers reporting relatively high levels of Children's Expression and Responsibility in their classrooms - which reflects the general agreement on the need to challenge the dominance of adult centred-agendas and structures (Thomas, 2007; Wyness, 2013) - it is possible that variability was not sufficient to result in significant associations and that this factor does not discriminate well teachers with medium to high-levels of support for participation. Therefore, with more variability, the factor reflecting constraints and restrictions to participation was more salient for identifying differences in perceived practices as a function of teachers' profiles of ideas.

The hypothesized association between ECE teachers' perceived participation practices, and children's perceived participation (H3), through observed participation practices ( $\mathrm{H} 4)$ and observed process quality (H5) was also partially confirmed. Specifically, decreased Decision Making by the Adult was associated with higher levels of Observed Children's Choice, which in turn were associated with higher levels of Children's Perceived Participation. Indeed, extant literature suggests that teachers with autonomy-supportive teaching styles value children's perspectives, actions, and decision- making (Reeve, 2009), thus leading to more participation opportunities perceived by the child (e.g., Correia \& Aguiar, 2017; Samuelsson, Sheridan, \& Williams, 2006). Therefore, consistent with Bronfenbrenner and Morris (2006), teachers' subjective reports of Decision Making by the Adult (i.e., a proxy for the levels of reciprocity in classroom processes) were associated with children's subjective experiences of participation, through observed (i.e., objective) features of the microsystem associated with children's agentic status. Note that we confirmed the mediating role of Observed

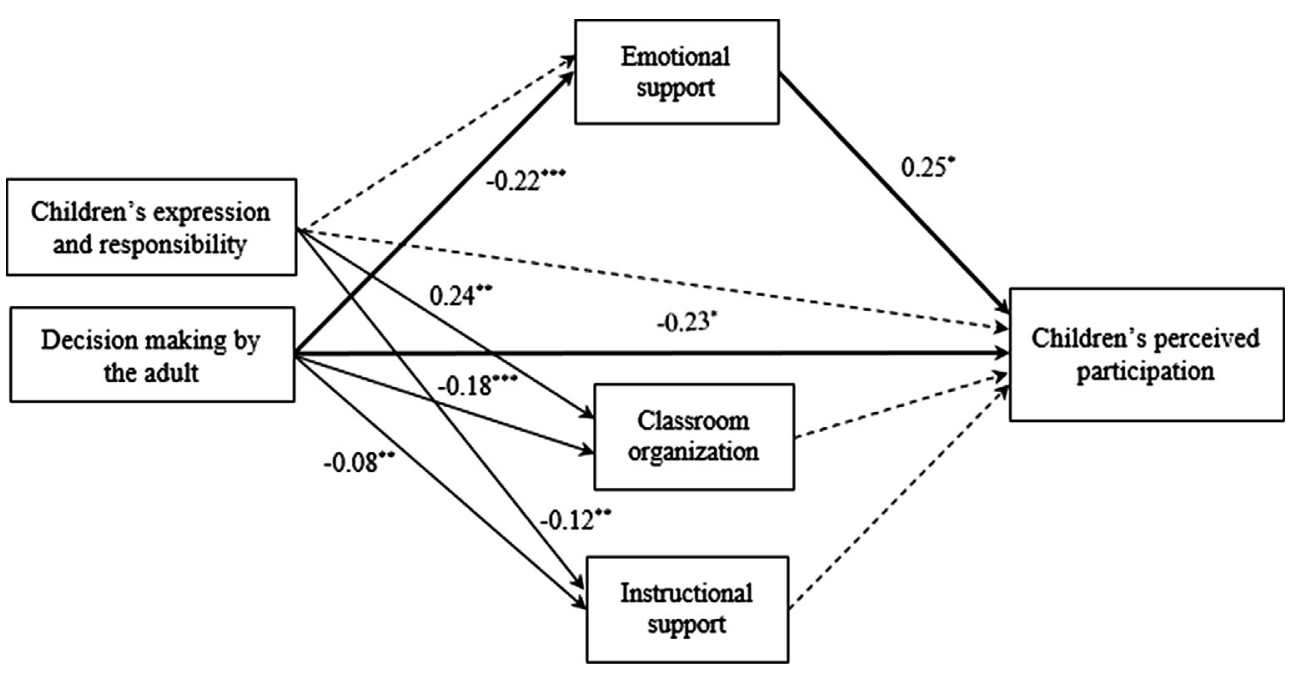

Fig. 5. Model examining domains of observed process quality as parallel multiple mediators of the relationship between teachers' perceptions of their participation practices, and children's perceived participation in the ECE setting. Dashed arrows refer to non-significant effects. Solid arrows refer to significant effects. Solid bold arrows refer to significant mediating effect and significant direct effect. ${ }^{*} p<.05$. ${ }^{* *} p<.01 .{ }^{* * *} p<.001$. 
Children's Choice, but not of Observed Conditions for Participation. This suggests that focusing on instances of children's choice and decision making may be more consequential to understanding associations between teachers' practices and children's perceived participation, than focusing on general practices establishing the conditions for participation.

Regarding observed process quality, we confirmed the mediating role of Emotional Support. Specifically, decreased Decision Making by the Adult, as perceived by ECE teachers, was associated with increased Emotional Support, which was associated with increased Perceived Participation by children. This finding is consistent with research focusing on the associations between participation and ECE quality (e.g., Correia \& Aguiar, 2017; Houen et al., 2016; Sheridan, 2007; Sheridan \& Samuelsson, 2001). Particularly, teachers in high-quality settings seem to promote more opportunities for children's decision making (Sheridan, 2007) and initiative (Houen et al., 2016). It is also consistent with research emphasizing the importance of teachers' sensitive and respectful attitudes (e.g., Bae, 2012; Freitas Luís et al., 2015; MesquitaPires, 2012). Emotional Support measures the extent to which teachers promote a positive climate in the ECE classroom, through positive relationships, affect, communication, and respect. Further, this dimension captures teacher sensitivity, involving teachers' awareness of and responsiveness to children's needs, assurance of children's comfort. Importantly, however, it also captures teachers' consideration for children's perspectives, through flexibility, child-centeredness, and support for child autonomy, leadership, and expression (Pianta et al., 2008). Therefore, this study provided evidence that teachers' subjective reports of Decision Making by the Adult (which reflect the levels of reciprocity in the classroom) were associated with children's subjective experiences of participation, through observed (i.e., objective) highquality proximal processes involving positive relationships, sensitiveness, and flexibility (Bronfenbrenner \& Morris, 2006).

It is noteworthy that Classroom Organization and Instructional Support (Pianta et al., 2008) did not mediate this association. Because these dimensions capture group and classroom management (e.g., setting behaviour rules and expectations) and the promotion of children's learning (e.g., facilitating concept and language development), respectively, our findings may reflect a closer conceptual alignment between participation practices and experiences and Emotional Support.

Taken together, our findings suggested that ECE teachers' ideas are associated with children's ideas, through practices. Importantly, these findings highlighted both the power of teachers' mental representations or belief systems and the capability of young children to assess and communicate about their participation experiences.

\subsection{Limitations}

First, we acknowledge the small size of our sample, resulting in limited statistical power. In this context, the fact that a considerable number of hypothesized associations were significant is noteworthy. Secondly, our study was conducted in the metropolitan area of Lisbon, a southern and non-interior region of Portugal, predominantly composed of urban and semi-urban areas. This regional, community-based sampling approach has consequences for the generalization of findings. As such, future studies should be conducted in more diverse geographical areas. Comparative cross-country studies are also warranted. Third, participant ECE teachers were exclusively women, which reflects the limited male representation in the Portuguese ECE workforce. Fourth, children in this study were aged between 44 and 84 months; therefore, future studies could also investigate younger children's ideas. Fifth, the same coders were responsible for conducting CLASS and participation practices' observations, raising issues of potentially shared variance. Sixth, while Emotional Support and Classroom Organization scores were reliable, interrater agreement estimates for Instructional Support scores were less than optimal. Finally, while we used both teacher reports and independent observations for assessing participation practices, we only collected children's perceptions of their participation experiences and did not specifically observe children's participation opportunities in each classroom.

\subsection{Implications and conclusions}

Our findings open new paths for future research. First, one possible direction would be to examine the extent to which classroom process quality (i.e., teacher-child interactions) varies as a function of teachers' profiles of ideas. Second, future research could, in alternative, explore the moderating role of teachers' ideas in the associations between teachers' practices and children's participation, investigating interaction effects between ideas and practices. Third, future studies could extend this work by analysing the associations between ECE teachers' ideas and participation practices and children's socio-cognitive outcomes. As widely stated in the literature, participation may be associated with children's self-esteem, self-efficacy, negotiation or conflict resolution (Kirby \& Bryson, 2002; Sinclair, 2004); therefore, future research could investigate participation-related benefits at the child level. Fourth, it is worth examining changes over time in teachers' ideas and practices, connecting with and extending previous research (e.g., Brownlee, 2003; Tarman, 2012).

This study also provided useful insights for ECE teachers' professional development. Specifically, increasing teachers' knowledge about participation benefits at the child level may be important to promote participation practices and increase the levels of reciprocity in classroom processes (i.e., redistributing power; Vieira, 2017), by reducing the focus on decision making by the adult. In addition, it may be necessary to address teacher attitudes towards supporting children's participation, by framing participation practices as part of the mission of ECE centres and workforce. Finally, supporting teachers in considering children's interests and perspectives and sharing decision making may help improve the overall quality of the classroom social climate and, ultimately, benefit individual children's subjective experiences in these settings and their opportunities for further development (Garbarino \& Ganzel, 2000).

Overall, this study contributed to a deeper understanding of the associations between teachers' and children's ideas regarding the right to participate in ECE settings, informing about the role of teachers' practices, both self-reported and observed, as the mechanisms that link teachers' and children's ideas. Further, by examining the link between teachers' ideas and practices towards the promotion of children's right to participate we advanced this field, while also providing an important contribution to the literature focusing on the associations between ideas and practices. Moreover, this was the first empirical effort to address associations between teachers' ideas, teachers' practices, and children's perceived participation, thus supporting the importance of considering not only different levels of analysis (i.e., teachers' ideas and practices; classroom and individual child levels), but also different informants (i.e., teachers, children, and independent observers), and methods (i.e., interviews, questionnaires, observation measures). Further, this study added to the literature, by giving voice to children in assessing their experiences. Hence, our findings provided support for framing participation as a complex, multi-layered concept (Herbots \& Put, 2015; Vieira, 2017). Ultimately, consistent with Bronfenbrenner and Morris (2006), our findings illustrated the interdependence of the subjective (i.e., perceived practices and experiences) and objective (i.e., observed practices) properties of ECE classrooms, and how both should inform our understanding of the conditions needed to promote children's participation.

Author Note

This work was funded by Portuguese National Funds, via FCT Fundação para a Ciência e a Tecnologia, through research grants awarded to the first author [SFRH/BD/96012/2013] and third author [SFRH/BD/92248/2013] and is a partial fulfillment of the requirements for the degree of Doctor in Psychology by the first author. 


\section{References}

Abreu-Lima, I. M., Leal, T. B., Cadima, J., \& Gamelas, A. M. (2013). Predicting child outcomes from preschool quality in Portugal. European Journal of Psychology of Education, 28(2), 399-420. https://doi.org/10.1007/s10212-012-0120-y.

Aguiar, A. L., Aguiar, C., Cadima, J., Correia, N., \& Fialho, M. (2019). Classroom quality and children's social skills and problem behaviors: Dosage and disability status as moderators. Early Childhood Research Quarterly, 49, 81-92. https://doi.org/10.1016/ j.ecresq.2019.05.005.

Alasuutari, M. (2014). Voicing the child? A case study in Finnish early childhood education. Childhood, 21(2), 242-259. https://doi.org/10.1177/0907568213490205.

AML [Área Metropolitana de Lisboa]. (2019). Retrieved from https://www.aml.pt/.

Araújo, S. C., \& Fernandes, N. (2016). A criança como sujeito de direitos no contexto da União Europeia: Nuances e diálogos necessários entre os direitos de participação e os direitos de proteção [The child as a rights' holder in the context of the European Union: Necessary nuances and dialogues between participation rights and protection rights]. In A. Bastos, \& F. Veiga (Eds.). A análise do bem-estar das crianças e jovens e os direitos da criança [Analysis of children and youth wellbeing and children's rights] (pp. 109-130). Famalicão, Portugal: Humus.

Bae, B. (2012). Children and teachers as partners in communication: Focus on spacious and narrow interactional patterns. International Journal of Early Childhood, 44(1), 53-69. https://doi.org/10.1007/s13158-012-0052-3.

Bauer, D., Preacher, K., \& Gil, K. (2006). Conceptualizing and testing random indirect effects and moderated mediation in multilevel models: New procedures and recommendations. Psychological Methods, 11, 142-163. https://doi.org/10.1037/1082989X.11.2.142.

Bronfenbrenner, U. (2005). Making human beings human: Bioecological perspectives on human development. Thousand Oaks, CA: Sage.

Bronfenbrenner, U., \& Morris, P. A. (2006). The bioecological model of human development. In W. Damon, \& R. M. Lerner (Eds.). Handbook of child psychology: Theoretical model of human development (pp. 793-828). New York, NY: John Wiley.

Broström, S., Sandberg, A., Johansson, I., Margetts, K., Nyland, B., Frøkjær, T., ... Vrinioti, K. (2015). Preschool teachers' views on children's learning: An international perspective. Early Child Development and Care, 185(5), 824-847. https://doi.org/10. 1080/03004430.2014.958483.

Brownlee, J. (2003). Changes in primary school teachers' beliefs about knowing: A longitudinal study. Asia-Pacific Journal of Teacher Education, 31(1), 87-98. https:// doi.org/10.1080/13598660301621.

Casas, F., Bello, A., González, M., \& Aligué, M. (2013). Children's subjective well-being measured using a composite index: What impacts Spanish first-year secondary education students' subjective well-being? Child Indicators Research, 6(3), 433-460. https://doi.org/10.1007/s12187-013-9182-x.

Clark, L. A., \& Watson, D. (1995). Constructing validity: Basic issues in objective scale development. Psychological Assessment, 7(3), 309-319. https://doi.org/10.1037/ 1040-3590.7.3.309.

Cohen, J. (1992). A power primer. Psychological Bulletin, 112(1), 155-159. https://doi. org/10.1037/0033-2909.112.1.155.

Conselho Nacional de Educação (2018). Estado da Educação 2017 - Edição 2018 [State of Education 2017-2018 Edition]. Lisboa: Conselho Nacional de Educação. http://www. cnedu.pt/content/EE2017/EE2017_04-03-2019.pdf.

Correia, N., \& Aguiar, C. (2017). Choosing classrooms: A structured interview on children's right to participate. International Journal of Educational Research, 82, 54-62. https://doi.org/10.1016/j.ijer.2017.01.004.

Correia, N., Carvalho, H., \& Aguiar, C. (2019). Teachers' ideas about children's right to participate in early childhood education. Manuscript submitted for publication.

Correia, N., Camilo, C., Aguiar, C., \& Amaro, F. (2019). Children's right to participate in early childhood education settings: A systematic review. Children and Youth Services Review, 100, 76-88. https://doi.org/10.1016/j.childyouth.2019.02.031.

Costello, A., \& Osborne, J. (2005). Best practices in Exploratory Factor Analysis: Four recommendations for getting the most from your analysis. Practical Assessment, Research \& Evaluation, 10(7), 1-9.

Council of Europe (2017). Young people's access to rights. Recommendation CM/Rec (2016)7 and explanatory memorandum. Retrieved from https://rm.coe.int/ $1680702 \mathrm{~b} 6 \mathrm{e}$.

Decree-Law No 240/2001. (2001). Ministério da Educação. Diário da República - Série I A - No.201 de 7 de 30 de agosto de, pp. 5569-5572.

Decree-Law No 241/2001. (2001). Ministério da Educação. Diário da República - Série I A - No.201 de 7 de 30 de agosto de, pp. 5572-5575.

Direção-Geral de Estatísticas da Educação e Ciência (2018). Estatísticas da educação 2017/ 2018 [Education statistics 2017/2018]. Lisboa: Direção-Geral de Estatísticas da Educação e Ciência. http://www.dgeec.mec.pt/np4/\%7B\$clientServletPath\%7D/? newsId $=1022 \&$ fileName $=$ EE_2018_Breve_s_ntese_de_resultados.pdf.

Direção-Geral de Estatísticas da Educação e Ciência (2019). Educação em números Portugal 2019 [Education in numbers - Portugal 2019]. Retrieved from http://www dgeec.mec.pt/np4/96/\%7B \$clientServletPath\%7D/?newsId = 145\&fileName $=$ DGEEC EN2019 201718.pdf.

Doverborg, E., \& Pramling, I. (1993). To understand children's thinking: Methods for interviewing children. Reports from Department of Methodology. University of Goteborg.

Eurochild (2015). Is Europe doing enough to invest in children? - 2015 Eurochild report on the European semester. Brussels, BE: Eurochild. https://www.eurochild.org/fileadmin/ public/05_Library/Thematic_priorities/02_Child_Poverty/Eurochild/Eurochild_ SemRep_FINAL.pdf.

European Commission (2013). Investing in children: Breaking the cycle of disadvantage. Official Journal of the European Commission.. http://eur-lex.europa.eu/legal-content/ EN/TXT/PDF/?uri = CELEX:32013H0112\&from $=$ EN .
European Commission/EACEA/Eurydice (2019). Key data on early childhood education and care in Europe: 2019 EditionEurydice Report. Luxembourg: Publications Office of the European Union.

Fives, H., \& Buehl, M. M. (2012). Spring cleaning for the "messy" construct of teachers' beliefs: What are they? Which have been examined? What can they tell us. In K. R. Harris, S. Graham, T. Urdan, S. Graham, J. M. Royer, \& M. Zeidner (Vol. Eds.), APA educational psychology handbook: Individual differences and cultural and contextual factors: Vol. 2, (pp. 471-499). Washington, DC: American Psychological Association.

Freitas Luís, J., Andrade, S., \& Santos, P. (2015). A atitude do educador de infância e a participação da criança como referenciais de qualidade em educação [The attitudes of early childhood education teachers and child participation as indicators of quality in education]. Revista Brasileira de Educação, 20(61), 521-541. https://doi.org/10. 1590/S1413-24782015206112.

Garbarino, J., \& Ganzel, B. (2000). The human ecology of early risk. In P. Shonkoff, \& S. J. Meisels (Eds.). Handbook of early childhood intervention (pp. 76-93). Cambridge, UK: Cambridge University Press.

Gates, P. (2006). Going beyond belief systems: Exploring a model for the social influence on mathematics teacher beliefs. Educational Studies in Mathematics, 63(3), 347-369. https://doi.org/10.1007/s10649-005-9007-z.

Hair, J., Anderson, R., Tatham, R., \& Black, W. (2010). Multivariate data analysis: a global perspective (7th ed.). Upper Saddle River, NJ: Pearson International Edition.

Harris, J., Spina, N., Ehrich, L., \& Smeed, J. (2013). Literature review: Student-centred schools make the difference. Melbourne, Australia: Australian Institute for Teaching and School Leadership/Queensland University of Technology.

Hart, R. (1992). Children's participation: From tokenism to citizenship. Florence, Italy: UNICEF International Child Development Centre.

Hart, C. S., \& Brando, N. (2018). A capability approach to children's well-being, agency and participatory rights in education. European Journal of Education, 53(3), 293-309. https://doi.org/10.1111/ejed.12284.

Hegde, A. V., \& Cassidy, D. J. (2009). Teachers' beliefs and practices regarding developmentally appropriate practices: A study conducted in India. Early Child Development and Care, 179(7), 837-847. https://doi.org/10.1080/03004430701536491.

Herbots, K., \& Put, J. (2015). The participation disc: A concept analysis of (a) child ('s right to) participation. The International Journal of Children's Rights, 23(1), 154-188. https://doi.org/10.1163/15718182-02301007.

Houen, S., Danby, S., Farrell, A., ... Thorpe, K. (2016). Creating spaces for children's agency: 'I wonder...' formulations in teacher-child interactions. International Journal of Early Childhood, 48(3), 259-276. https://doi.org/10.1007/s13158-016-0170-4.

Hox, J. (2010). Multilevel analysis: Techniques and applications (2nd ed.). New York, NY: Routledge.

Hu, L. T., \& Bentler, P. M. (1999). Cutoff criteria for fit indexes in covariance structure analysis: Conventional criteria versus new alternatives. Structural Equation Modeling, 6, 1-55. https://doi.org/10.1080/10705519909540118.

James, A. (2007). Giving voice to children's voices: Practices and problems, pitfalls and potentials. American Anthropologist, 109(2), 261-272. https://doi.org/10.1525/aa. 2007.109.2.261.

Johansson, I., \& Sandberg, A. (2010). Learning and participation: Two interrelated keyconcepts in the preschool. European Early Childhood Education Research Journal, 18(2), 229-242. https://doi.org/10.1080/13502931003784560.

Kenny, D. A., Kaniskan, B., \& McCoach, D. B. (2015). The performance of RMSEA in models with small degrees of freedom. Sociological Methods \& Research, 44(3), 486-507. https://doi.org/10.1177/0049124114543236.

Kids Rights Foundation (2019). The KidsRights Index 2019. Amsterdam, NL: KidsRights Foundation. Retrieved from https://www.kidsrightsindex.org/Portals/5/KRI \%202019/The\%20KidsRights\%20Index\%202019\%20Report.pdf?ver = 2019-05-09150422-647.

Kirby, P., \& Bryson, S. (2002). Measuring the magic? Evaluating and researching young people's participation in public decision making. London, United Kingdom: Carnegie Young People Initiative.

Kline, R. (2011). Principles and practice of structural equation modelling (3rd ed.). New York, NY: Guilford Press.

Knauf, H. (2017). Documentation as a tool for participation in German early childhood education and care. European Early Childhood Education Research Journal, 25(1), 19-35. https://doi.org/10.1080/1350293X.2015.1102403.

Koran, N., \& Avci, N. (2017). Perceptions of prospective pre-school teachers regarding children's right to participate in classroom activities. Educational Sciences: Theory \& Practice, 17(3), 1035-1059. https://doi.org/10.12738/estp.2017.3.0325.

Lansdown, G. (2010). The realisation of children's participation rights: Critical reflections. In B. Percy-Smith, \& N. Thomas (Eds.). A handbook of children and young people participation (pp. 33-45). New York, NY: Routledge.

Law No 4/97. (1997). Presidência do Conselho de Ministros. Diário da República, $1^{\text {a }}$ série A - No $7-9$ de janeiro de, pp. 72-74. Retrieved from https://dre.pt/application/ file/a/67649251.

Law No 65/2015. (2015). Ministério da Educação. Diário da República - 1a Série no. 128 -3 de Julho de, p. 4572. Retrieved from https://dre.pt/application/file/a/67649251.

Lloyd, K., \& Emerson, L. (2017). (Re) examining the relationship between children's subjective wellbeing and their perceptions of participation rights. Child Indicators Research, 10(3), 591-608. https://doi.org/10.1007/s12187-016-9396-9.

Lopes, L., Correia, N., \& Aguiar, C. (2016). Implementação do direito de participação das crianças em contexto de jardim de infância: As perceções dos educadores. Revista Portuguesa de Educação, 29(2), 81-108. https://doi.org/10.21814/rpe.6560.

Lopes Da Silva, L., Marques, I., Mata, L., \& Rosa, M. (2016). Orientações curriculares para a educação pré-escolar [Curriculum guidelines for preschool education]. Lisboa, Portugal: Ministério da Educação/Direção-Geral da Educação (DGE). http://www.dge.mec.pt/ sites/default/files/Noticias_Imagens/ocepe_abril2016.pdf.

Lundy, L. (2007). 'Voice' is not enough: Conceptualising Article 12 of the United Nations 
convention on the rights of the child. British Educational Research Journal, 33(6), 927-942. https://doi.org/10.1080/01411920701657033.

Mashford-Scott, A., \& Church, A. (2011). Promoting children's agency in early childhood education. Novitas-ROYAL, 5(1), 15-38.

Melhuish, E. (2014). The impact of early childhood education and care on improved wellbeing. In British Academy (Ed.). "If you could do one thing...": Nine local actions to reduce health inequalities. London, UK: British Academy.

Mesquita-Pires, C. (2012). Children and professionals' rights to participation: A case study. European Early Childhood Education Research Journal, 20(4), 565-576. https:// doi.org/10.1080/1350293X.2012.737242.

Moser, T., Leseman, P., Melhuish, E., Broekhuizen, M., \& Slot, P. (2017). European framework of quality and wellbeing indicators. Report D6.3, CARE: Curriculum quality analysis and impact review of European early childhood education and care. Vestfold, NO: University College of Southwest Norway.

Muthén, B., \& Satorra, A. (1995). Technical aspects of Muthén's LISCOMP approach to estimation of latent variable relationships with a comprehensive measurement model. Psychometrika, 60, 489-503. https://doi.org/10.1007/BF02294325.

Nah, K. O., \& Lee, S. M. (2016). Actualizing children's participation in the development of outdoor play areas at an early childhood institution. Action Research, 14(3), 335-351. https://doi.org/10.1177/1476750315621610.

Niemi, R. (2019). From active joining to child-led participation: A new approach to examine participation in teaching practice. South African Journal of Childhood Education, 9(1), 1-7. https://doi.org/10.4102/sajce.v9i1.663.

O'Connor, B. (2000). SPSS and SAS programs for determining the number of components using parallel analysis and Velicer's MAP test. Behavior Research Methods, Instrumentation, and Computers, 32, 396-402. https://doi.org/10.3758/BF03200807.

OECD (2009). Creating effective teaching and learning environments: First results from TALIS. Paris, France: OECD Publishing.

OECD (2018). Education at a glance 2018: OECD indicators. Paris, France: OECD Publishing.

Oliveira-Formosinho, J., \& Lino, D. (2008). Os papéis das educadoras: As perspectivas das crianças [Teachers' roles: Children's Perspectives]. In J. Oliveira-Formosinho (Ed.). A escola vista pelas crianças (pp. 55-74). Porto, Portugal: Porto Editora.

Pajares, M. F. (1992). Teachers' beliefs and educational research: Cleaning up a messy construct. Review of Educational Research, 62(3), 307-332. https://doi.org/10.3102/ 00346543062003307.

Pettersson, K. E. (2015). Children's participation in preschool documentation practices. Childhood, 22(2), 231-247. https://doi.org/10.1177/0907568213513480.

Pianta, R. C., LaParo, K. M., \& Hamre, B. K. (2008). Classroom Assessment Scoring System Manual: Pre- K. Baltimore, MD: Brookes.

Pinto, A. I., Pessanha, M., \& Aguiar, C. (2013). Effects of home environment and centerbased child care quality on children's language, communication, and literacy outcomes. Early Childhood Research Quarterly, 28, 94-101. https://doi.org/10.1016/j. ecresq.2012.07.001.

Preacher, K. J., \& Hayes, A. F. (2008). Asymptotic and resampling strategies for assessing and comparing indirect effects in multiple mediator models. Behavior Research Methods, 40(3), 879-891. https://doi.org/10.3758/BRM.40.3.879.

Preacher, K. J., \& Selig, J. P. (2012). Advantages of Monte Carlo confidence intervals for indirect effects. Communication Methods and Measures, 6(2), 77-98. https://doi.org/ 10.1080/19312458.2012.679848.

Reeve, J. (2009). Why teachers adopt a controlling motivating style toward students and how they can become more autonomy supportive. Educational Psychologist, 44(3), 159-175. https://doi.org/10.1080/00461520903028990.

Salminen, J. E. (2013). Case study on teachers' contribution to children's participation in Finnish preschool classrooms during structured learning sessions. Frontline Learning Research, 1(1), 72-80. https://doi.org/10.14786/flr.v1i1.31.

Samuelsson, I. P., Sheridan, S., \& Williams, P. (2006). Five preschool curricula: Comparative perspective. International Journal of Early Childhood, 38(1), 11-29. https://doi.org/10.1007/bf03165975.

Sandberg, A., \& Eriksson, A. (2010). Children's participation in preschool: On the conditions of the adults? Preschool staff's concepts of children's participation in preschool everyday life. Early Child Development and Care, 180(5), 619-631. https://doi. org/10.1080/03004430802181759.

Sandseter, E., \& Seland, M. (2016). Children's experience of activities and participation and their subjective well-being in Norwegian early childhood education and care institutions. Child Indicators Research, 9(4), 913-932. https://doi.org/10.1007/ s12187-015-9349-8.

Save the Children (2005). Practice standards in children's participation. London, UK: Save the Children Foundation. https://resourcecentre.savethechildren.net/node/3017/ pdf/3017.pdf.

Sheridan, S. (2007). Dimensions of pedagogical quality in preschool. International Journal of Early Years Education, 15(2), 197-217. https://doi.org/10.1080/ 09669760701289151.

Sheridan, S., \& Samuelsson, I. P. (2001). Children's conceptions of participation and influence in pre-school: A perspective on pedagogical quality. Contemporary Issues in Early Childhood, 2(2), 169-194. https://doi.org/10.2304/ciec.2001.2.2.4.

Sigel, I. E. (1985). Parental belief systems: The psychological consequences for children (1st ed.). Hillsdale, NJ: Lawrence Erlbaum Associates.

Sinclair, R. (2004). Participation in practice: Making it meaningful, effective and sustainable. Children \& Society, 18, 106-118. https://doi.org/10.1002/chi.817.

Smith, A. B. (2002). Interpreting and supporting participation rights: Contributions from sociocultural theory. International Journal of Children's Rights, 10, 73-78. https://doi. org/10.1163/157181802772758137.

Snijders, T., \& Bosker, R. (2003). Multilevel analysis: An introduction to basic and advanced multilevel modeling. London: Sage.

Tarman, B. (2012). Prospective teachers' beliefs and perceptions about teaching as a profession: Educational Sciences. Theory and Practice, 12(3), 1964-1973.

Theobald, M., \& Kultti, A. (2012). Investigating child participation in the everyday talk of a teacher and children in a preparatory year. Contemporary Issues in Early Childhood, 13(3), 210-225. https://doi.org/10.2304/ciec.2012.13.3.210.

Tholin, K. R., \& Jansen, T. T. (2012). Something to talk about: Does the language use of pre-school teachers invite children to participate in democratic conversation? European Early Childhood Education Research Journal, 20(1), 35-46. https://doi.org/ 10.1080/1350293X.2012.650010.

Thomas, N. (2007). Towards a theory of children's participation. The International Journal of Children's Rights, 15(2), 199-218. https://doi.org/10.1163/092755607X206489.

Thornberg, R., \& Elvstrand, H. (2012). Children's experiences of democracy, participation, and trust in school. International Journal of Educational Research, 53, 44-54. https://doi.org/10.1016/j.ijer.2011.12.010.

Turnšek, N. (2008). Factors determining children's decision-making in Slovene preschools. Odgojne Znanosti, 10(16), 23-38.

UNICEF (2019). A world ready to learn: Proritizing quality early childhood education. Global report. New York, NY: UNICEF. https://www.unicef.org/reports/a-world-ready-tolearn-2019.

United Nations Committee on the Rights of the Child (2005). General comment No 7 (2005): Implementing child rights in early childhood. Retrieved from www.refworld. org/docid/460bc5a62.html.

United Nations Committee on the Rights of the Child (2009). Convention on the Rights of the Child: General comment no 12. The right of the child to be heard. Retrieved from www.refworld.org/docid/4ae562c52.html.

United Nations General Assembly (1989). The United Nations convention on the rights of the child. New York, NY: United Nations.

Vieira, I. F. (2017). A participação: Um paradigma para a intervenção social [Participation: A paradigm for social intervention]. Lisboa, Portugal: Universidade Católica Editora.

Wilcox-Herzog, A. S. (2002). Is there a link between teachers' beliefs and behaviors? Early Education and Development, 13(1), 81-106. https://doi.org/10.1207/ s15566935eed1301_5.

Wilcox-Herzog, A. S., Ward, S. L., Wong, E. H., \& McLaren, M. S. (2015). Preschool teachers' ideas about how children learn best: An examination of beliefs about the principles of developmentally appropriate practice. In H. Fives, \& M. G. Gill (Eds.). International handbook of research on teachers' beliefs (pp. 421-435). New York, NY: Routledge.

Wyness, M. (2013). Children's participation and intergenerational dialogue: Bringing adults back into the analysis. Childhood, 20(4), 429-442. https://doi.org/10.1177/ 0907568212459775.

Zorec, M. B. (2015). Children's participation in Slovene preschools: The teachers' viewpoints and practice. European Education, 47(2), 154-168. https://doi.org/10.1080/ 10564934.2015.103987. 